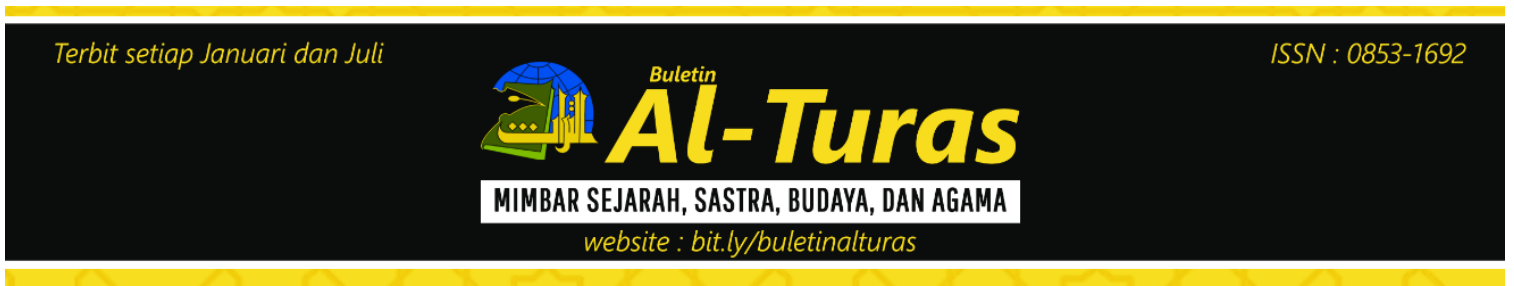

\title{
Pengaruh Perang Dunia II Terhadap Revolusi Mesir 1952
}

\author{
Shalahuddin al-Ayubbi
}

\begin{abstract}
The french emperor, Napoleon, who inhabited Egypt, had introduced the modern civilization of Arab in 1798 to the world. Besides, Franch also introduced the modern products. As the result, many muslims began to have a new view of the time. Turk as a new ruler of muslims world had to take a part for it. It delegated Muhammad Ali Pasha to expelled Franch from Egypt. After finishing the exhausting war, he finally conquered French. Soon, Muhammad Ali Pasha confirmed himself as a new ruler of Egypt and continued the new project which was planned by Franch. World of Islam began to flared up after Germany had been defeated during the World War I in 1918, where Turk joined in it. Egypt were handed down to England as the winner. By the beginning of World War II, Egypt were still controlled by England. It can be seen from the Egypt where allied force base was put in it during the defeat of Germany in North Africa on November 1942. World War II was ended by the allies glory and the the loses of Germany and its supporters. Despite of Egypt had not involved, however, the effects of world War II had arisen the nationalism to get rid of local ruler as the British representative. In addition to this, the glory of Russia as one of the participants of World War II had brought a new view of socialism into Egypt which was adapted by free movement as the basic ideology and values. Next, the free movement opsir who cooperated with Ikhwanul Muslimin became the intellectual actor and locomotive for people in Egypt to have revolution in 1952.

Keywords: French emperor, modern civilization, revolution, world war II, Egypt.
\end{abstract}

Abstrak
Pendudukan Mesir oleh Napoleon, Kaisar Prancis, pada tahun 1798 memperkenalkan dunia Arab dengan peradaban modern. Selain menjajah, Prancis juga mengenalkan produk-produk peradaban yang baru. Alhasil, orang Islam mulai mengenal berbagai wacana terbaru di masa itu. Turki sebagai penguasa dunia Islam tidak tinggal diam. Ia mengutus Muhammad Ali Pasha untuk mengusir Prancis dari Mesir. Setelah melalui peperangan yang melelahkan akhirnya Prancis dapat dikalahkan. Tak lama kemudian, Muhammad Ali mentahbiskan diri sebagai penguasa Mesir dan melanjutkan proyek pembaruan yang sebelumnya diletakkan oleh Prancis. Dunia Islam kembali bergolak, paska kekalahan blok Jerman dalam Perang Dunia I pada 1918, dimana Turki tergabung di dalamnya. Mesir jatuh ke tangan Inggris sebagai bagian dari pemenang perang. Hingga awal Perang Dunia II, Mesir masih berada di tangan Inggris. Hal ini ditunjukkan dengan dijadikannya Mesir sebagai pangkalan perang Sekutu ketika mengalahkan tentara Jerman di front Afrika Utara pada bulan November 1942. Perang Dunia II diakhiri dengan kemenangan Sekutu dan kekalahan Jerman dan pendukungnya. Meskipun Mesir tidak terlibat langsung, pengaruh PD II sangat kental dalam menumbuhkembangkan semangat nasionalisme untuk bebas dari cengkeraman penguasa lokal yang menjadi wakil dari Inggris. Selain itu, kemenangan Rusia sebagai salah satu peserta PD II, ikut membawa wacana sosialisme ke Mesir yang diadopsi oleh gerakan Opsir Bebas sebagai ideologi dan nilai dasar pergerakannya. Selanjutnya, Opsir Bebas yang telah bekerja sama dengan Ikhwanul Muslimin menjadi aktor intelektual dan penggerak bagi rakyat Mesir untuk menjemput revolusi pada tahun 1952.

Kata Kunci: penguasa perancis, peradaban modern, revolusi, perang dunia II, Mesir. 


\section{A. Pendahuluan}

Inggris telah berhasil mengusir Italia dari tanah Mesir, kemenangan ini sangatlah gemilang dengan taktik melakukan serangan langsung kepada pasukan Italia yang sedang melakukan mogok kerja kepada Bennito Mussolini karena Bennito Mussolini tidak mengirimkan senjata baru dan juga logistik tambahan untuk pasukan yang sedang bertahan di tengah gurun pasir yang sangat tidak bersahabat.

Hitler yang telah mendengar kabar bahwa pasukan Italia telah dipukul mundur dari wilayah Afrika Utara langsung geram dan merasa harga dirinya diinjak-injak karena negara sahabatnya Italia telah dihina oleh Inggris. Hitler langsung mengirimkan pasukannya untuk melawan pasukan Inggris di Afrika Utara, di bawah pimpinan Jendral Erwin Rommel. Pada tanggal 12 Februari 1941, Jendral Erwin Rommel telah tiba di Tripoli, Libya. Erwin Rommel memperkuat divisinya dengan menerjunkan Divisi Bermotor dan dua bulan kemudian diperkuat lagi dengan Divisi Lapis Baja. Di Tripoli, Libya Jendral Erwin Rommel masih memiliki atasan yang bernama Jendral Italo Gariboldi. Jendral Italo Gariboldi adalah pemimpin pasukan Italia di Libya, di bawah pimpinan Gariboldi, akhirnya Rommel bisa melakukan penyerangan koalisi gabungan antara Jerman-Italia. ${ }^{1}$

Jendral Wavell dari Inggris menduga bahwa pasukan Jerman pasti tidak akan berani melakukan penyerangan sebelum bantuan senjata dan tank datang. Ternyata dugaannya salah besar. Rommel adalah tipe pemimpin yang tidak suka menunggu terlalu lama dalam melakukan penyerangan. Lalu Rommel langsung meminta restu kepada Jendral Italo Gariboldi untuk melakukan penyerangan kepada Inggris. Semula Jendral Italo Gariboldi tidak setuju kalau Rommel langsung melakukan penyerangan, tetapi Rommel memberikan beberapa alasan kenapa Inggris harus diserang saat ini juga, yaitu adalah karena pertahanan Inggris sedang lemah-lemahnya karena Inggris sedang berkonsentrasi untuk menyerbu Yunani dan tidak terlalu memikirkan pertahanan di Mesir.

Setelah mendapatkan restu dari Jendral Gariboldi, Rommel langsung melakukan penyerangan kepada Inggris. Pada tanggal 31 Maret 1941, Rommel menyerang kota Mersa Brega yang sudah diduduki oleh Inggris sebelumnya. Benar saja, seperti diduga Rommel posisi Inggis sedang lemah. Setelah Rommel membawa pasukannya untuk menyerbu. Inggris belum mempunyai persiapan yang matang dan akhirnya Inggris melarikan diri pada saat serangan dari Jendral Rommel berlangsung. Penyerangan yang dilakukan oleh Rommel tidak terlalu jauh dari posisi pertahanan sebelumnya dikarenakan kondisi alam yang sangat keras dan sulit untuk ditaklukan tanpa ada persiapan yang cukup atau air.

Salah satu kelemahan dari pasukan Jerman-Italia adalah distribusi logistik ke medan pertempuran. Logistik lebih sering di antar melalui udara, dan laut untuk memenuhi kebutuhan pasukan Jerman-Italia yang sedang melakukan perlawanan terhadap Inggris. Pada bulan Juli 1941, Inggris berhasil menemukan kelemahan dari pasukan Jerman dan Italia yang menyerangnya. Dalam waktu singkat Inggris menghancurkan jalur utama logistik di udara dan di laut yang dikirim oleh Jerman dan Italia.

Seharusnya Jerman dan Italia bisa melakukan serangan balik dan memberikan perlindungan terhadap logistik yang akan dikirim melalui udara dan laut. Tetapi karena kedua negara ini sedang fokus dalam penyerangan kepada Soviet akhirnya menyebabkan invasi yang dilakukan ke Mesir menjadi tidak terpusat dan tidak fokus. Dari sinilah dimulai kemunduran pasukan Italia dan Jerman yang berada di Mesir. Inggris yang semula digempur mundur oleh pasukan yang dibawa oleh Rommel, mendapatkan bantuan 300 tank Sherman yang berasal dari Amerika Serikat. Konon, menurut Amerika Serikat tank Sherman ini 
adalah tank yang bisa mengalahkan Panzer milik Jerman. ${ }^{2}$

Setelah Inggris mendapatkan bala bantuan dari Amerika Serikat, Inggris langsung memberikan serangan dadakan. Dengan tank yang hanya tersisa 25 buah, Rommel mencoba bertahan namun tetap tidak bisa bertahan dari serangan 300 tank yang digunakan Inggris untuk memukul mundur pasukan Rommel. Rommel dengan sedikit tenaga yang tersisa meminta agar Italia mengirmkan bantuannya kepada Rommel.

Namun setelah bantuan yang dikirimkan ternyata dihalau oleh pasukan Inggris dengan puluhan terpedonya sehingga memutus logistik untuk Rommel. Akhirnya Rommel beserta pasukannya mundur dari Mesir dan kembali ke pertahanannya di negara tetangga Mesir yaitu Libya.

Perang Dunia II berakhir dengan kekalahan telak di pihak kekuatan poros yang digawangi oleh Jerman, Italia dan Jepang. Akibat kekalahan ini, Jerman terpaksa harus melakukan perjanjian perdamaian dalam Konferensi Postdam 2 Agustus 1945 yang diadakan oleh Sekutu untuk menghukum Jerman sebagai negara yang kalah. Konferensi Postdam ini di hadiri oleh Truman, Stalin, dan Atlee. Dalam konferensi, dihasilkan beberapa keputusan diantaranya: ${ }^{3}$

- Jerman akan dibagi menjadi 4 daerah kependudukan yaitu bagian timur akan dipegang oleh Rusia, bagian barat oleh Amerika Serikat, Inggris dan Perancis. Selain itu, Kota Berlin yang terletak di tengah- tengah daerah pendudukan Rusia dibaagi menjadi 4 bagian, yaitu Berlin Barat yang dikuasai oleh Amerika Serikat, Inggris, Perancis dan Berlin Timur yang dikuasai oleh Rusia sendiri.

- Danzig dan daerah Jerman di sebelah timur Sungai Oder dan Neisse diberikan kepada Polandia.

\footnotetext{
${ }^{2}$ www.militaryhistory.about.com diases pukul 07:22 tanggal 15 Nopember 2012

${ }^{3}$ Marbun, Demokrasi Jerman, hlm. 58-72.
}

- Diberlakukannya demiliterisasi bagi angkatan perang Jerman.

- Tahanan perang Nazi akan diawasi oleh pengawasan Internasional.

- Terakhir Jerman harus membayar kerugian yang diciptakannya kepada Sekutu.

Kekalahan Jerman ini telah menghancurkan garis pertahanan yang dibuat oleh Jerman di Italia sejauh 125 $\mathrm{km}, 20.000-30.000$ ribu tentara Jerman ditahan oleh sekutu. Hingga akhirnya sang Fuhrer mundur dan bersembunyi di dalam bunker ciptaannya bersama dengan istrinya. $^{4}$ Kematian sang Fuhrer sangat tragis, yaitu dengan menembakkan kepalanya dengan peluru tajam.

\section{B. Pembahasan}

\section{Mesir Pasca Perang Dunia II}

Perang Dunia II yang telah berkecamuk di belahan Eropa berdampak negatif terhadap seluruh negara di dunia manapun. Mesir yang telah lama wilayahnya diduduki oleh Inggris, lama kelamaan sadar akan buruknya sistem pemerintahan yang dibuat oleh Inggris.

Perang Dunia II juga telah menyadarkan bangsa Mesir terhadap kegagalan pemerintahan liberal dan konstitusional Eropa. Bangsa Eropa yang singgah di Mesir semata-mata membuat konstitusi pemerintahan yang hanya pro kepada masyarakat di Eropa saja tetapi tidak kepada masyarakat Mesir. Masyarakat Mesir yang semakin lama semakin tidak suka keberadaan Inggris di Mesir langsung merencanakan untuk mengusir Inggris dari Mesir dan membangkitkan kembali semangat bangsa Mesir.

Pada dekade 1930 dan 1940an, kebangkitan Mesir mulai melibatkan para ulama tradisional dan tokoh sufi yang posisi politik dan ideologisnya tidak mampu menentang otoritas pemerintah. Beberapa perwakilan perhimpunan

\footnotetext{
${ }^{4}$ http://www.archives.com/genealogy/newspapergenealogy-world-war-2.html diakses pada pukul 20.00 WIB pada tanggal 16 Desember 2012
} 
pemuda Islam yang ada di Mesir juga menyerukan penolakan terhadap pendudukan asing yang telah banyak tersebar di Mesir.

Dari kumpulan pemuda Islam ini, dibentuklah suatu wadah yang bertujuan untuk mengusir orang Eropa dari tanah Mesir. Meminjam teori Emile Durkheim, hal ini disebut dengan solidaritas sosial dimana suatu masyarakat yang mempunyai masalah sosial yang sama dan ingin menyelesaikan masalah itu secara kolektif. Wadah ini dinamakan dengan Ikhwanul Muslimin dan didirikan oleh Hasan Al- Banna salah satu orang promotor dan perekrut anggota Ikhwanul Muslimin.

Hasan Al-Banna memulai mencari simpatisan untuk gerakan Ikhwanul Muslimin dari kalangan orang-orang strata sosial paling bawah. Menurut Hasan AlBanna, orang-orang yang dengan strata sosial paling bawah ini sangat mudah untuk didekati dan diajak bergabung dalam gerakan Ikhwanul Muslimin. Kebencian Hasan Al-Banna terhadap asing sudah lama terpendam ketika orang-orang Eropa yang berada di Mesir hanya memikirkan bangsa Eropa saja, dan bangsa Non Eropa hanya dijadikan budak di tanah sendiri.

Sistem perekonomian Mesir sudah dikuasai oleh Inggris sejak Perang Dunia I hingga akhir Perang Dunia II, sehingga masyarakat di Mesir hanya mengelola dan menggarap apa yang jadi penghasilan mereka tanpa mendapatkan hasil yang maksimal dari tanah yang dipunyai oleh masyarakat Mesir sendiri.

Hasan Al-Banna sadar akan keterpurukan bangsa Mesir yang berada di bawah tangan orang-orang Eropa dan berusaha menjalin hubungan dengan beberapa perwira militer di Mesir untuk melawan bangsa Eropa dan menggulingkan Raja Farouk yang selama ini diam oleh Inggris dan tidak ada pembelaan sama sekali. Raja Farouk semakin dibenci oleh rakyatnya karena sifat Raja Farouk yang semakin tidak menunjukkan sosok raja seperti ayahnya
Raja Fuad I. Raja Farouk adalah Raja yang sering menghambur-hamburkan hartanya disaat masyarakat Mesir sedang mengalami kesulitan karena efek dari Perang Dunia. Pada saat Perang Dunia II juga pernah terjadi saat Italia menginvasi Mesir, seluruh masyarakat Mesir memadamkan lampu untuk mengelabuhi Invasi Bangsa Italia, tetapi Raja Farouk malah menghidupkan semua lampu di kerjaannya dan memboroskan semua energi listrik yang ada di Mesir. Selanjutnya, pada saat Perang Dunia II ketika Mesir sedang diserang para penjajah yang berasal dari Jerman dan Italia, Raja Farouk malah mengadakan kunjungan ke negara lain dan berbelanja menghambburhamburkan hartanya tanpa memperdulikan masyarakatnya yang sedang kesulitan bertahan karena serangan Jerman dan Italia.

Raja Farouk adalah Raja yang cukup dekat dengan Inggris, bahkan sempat dikatakan oleh John L Esposito dalam buku Ancaman Islam: Mitos Atau Realiti bahwa Raja Farouk adalah kaki tangan dari Sekutu. Kebangkitan nasionalisme dan anti Eropa mulai dipupuk masyarakat Arab dimulai ketika Ikhwanul Muslimin yang diprakarsai oleh Hasan Al-Banna bergabung dengan Militer di bawah pimpinan Gamal Abdul Nasser. Ikhwanul Muslimin mendapatkan dukungan dari masyarakat yang nasionalismenya dibangkitkan oleh Hasan Al-Banna melalui perjalanannya menemui setiap masyarakat Mesir yang strata sosialnya ada dibawah garis kemiskinan di warung-warung kopi tempat berkumpul. ${ }^{5}$

\section{Penggulingan Raja Farouk}

Kondisi Mesir selama berada di bawah genggaman Inggris dan kaki tangannya, Raja Farouk membuat masyarakat Mesir geram. Terlebih ketika hegemoni yang digunakan oleh Inggris dan Raja Farouk diterapkan di Mesir pada

\footnotetext{
${ }^{5}$ John L Esposito, Ancaman Islam: Mitos atau Realiti, (Kuala Lumpur: PTS Publication, 2004) hlm. 96.
} 
tahun 1920. Fase liberalisme di Mesir ini mulai memanjangkan kepentingannya ke berbagai bidang seperti perekonomian, politik, dan juga pendidikan.

Di bidang perekonomian, mulai dibangun sejumlah bank selanjutnya mulai dibentuk beberapa partai politik untuk mengakomodasi kepentingan politik warga Mesir. Di bidang pendidikan, mulai banyak dibangun perguruan tinggi bernuansa modern sebagai respon tuntutan zaman dan juga berbagai tempat hiburan dibangun di Mesir seperti bioskop dan teater. Padahal pada zaman itu keadaan masyarakat Mesir sedang sulit akibat Perang Dunia II tetapi Raja Farouk tetap tidak peduli dengan keadaan masyarakatnya. ${ }^{6}$

Liberalisasi di Mesir ini banyak ditentang oleh kalangan konservatif dan tradisionalis yang mulai bermunculan di Mesir, seperti gerakan politik Ikhwanul Muslimin yang menginginkan ditegakkannya syariat Islam dalam ranah politik. Gerakan politik Ikhwanul Muslimin ini tentunya tidak akan terwujud jika masih ada orang Eropa yang menyebarkan paham Liberalis. Akhirnya, Ikhwanul Muslimin mendekatkan organisasinya dan bekerja sama dengan elemen perwira bebas, yakni sejumlah elite menengah militer yang kemudian akan menjadi aktor utama dalam revolusi 1952.

Hasan Al Banna dan Mursyid Am Ikhwan mulai mengontak anggota militer yang bernama Anwar Sadat seorang junta militer selanjutnya melalui Anwar Sadat mulai dihubungkan lagi dengan Aziz Al Misri seorang mantan Panglima Angkatan Tertinggi Angkatan Bersenjata Mesir yang sudah menjadi Purnawirawan. Selanjutnya militer yang dihubungi oleh Ikhwanul Muslimin adalah Mahmud Labib yang membantu Abdul Rauf untuk menghubungkan kepada Gamal Abdul Nasser. Dari dekatnya hubungan antara Gamal Abdul Nasser dan Ikhwanul Muslimin, sebagian besar perwira ikut masuk kedalam gerakan politik yang dimotori oleh Ikhwanul Muslimin.

Pada akhir tahun 1950, Raja Farouk mulai curiga bahwa militer sudah mulai banyak yang menjalin hubungan dengan Ikhwanul Muslimin dan menduga bahwa akan ada gerakan untuk menggulingkannya dari tampuk kekuasaan karena selama ini Ikhwanul Muslimin gencar meneriakkan ketidaksukaannya kepada Raja Farouk.

Gerakan revolusi yang akan dibuat oleh Ikhwanul Muslimin dan Perwira Militer Bebas sudah semakin tercium oleh Raja Farouk. Untuk mengantisipasi segala kemungkinan terburuk, Gamal Abdul Nasser menyelundupkan senjata menyembunyikan di rumah milik Muhammad Al-Asymawi, ayah dari Hasan Asymawi, teman terdekat Gamal Abdul Nasser di gerakan Ikhwanul Muslimun.

Menjelang revolusi, hubungan antara Ikhwanul Muslimin dan Perwira bebas semakin dekat dan dijelaskan oleh para perwira bebas bahwa revolusi ini sangat membutuhkan banyak dukungan dan massa. Maka para Perwira Bebas ini menyerahkan kepada Ikhwanul Muslimin untuk mencari massa dan dukungan sebanyak-banyaknya serta mempropaganda dan mempengaruhi masyarakat Mesir yang bukan berasal dari Ikhwanul Muslimin untuk bergabung memperjuangkan kebebasan Mesir dari cengkraman tangan Inggris dan Raja Farouk.

Semula rencana revolusi ini akan dilakukan pada tanggal 25 Maret, tetapi ternyata diundur dan baru dilakukan pada tanggal 23 Juli 1952, setelah upaya istana yang gagal untuk memenangkan orang pilihannya menjadi perhimpunan kepala perwira. Sikap resmi organisasi Ikhwanul Muslimin ketika itu terhadap revolusi 1952 dapat dilihat dari tindakan Hasan AlHudhaibi dan Mursyid Am yang tidak memberikan pernyataan sikap apapun mengenai peristiwa revolusi. Richard Paul Mitchell menilai sikap yang diambil oleh Hudhaibi tersebut merupakan sikap 
kehat i- hatian karena perencanaan dan situasi yang mengitari pemberontakan (revolusi) Perwira Bebas telah dibebankan diatas penggung Ikhwanul Muslimin. Dengan kata lain, Ikhwanul Muslimin dijadikan sebagai kendaraan revolusi oleh perwira bebas. $^{7}$

Alasan Ikhwanul Muslimin mau dijadikan kendaraan revolusi bisa dilihat dari latar belakang yang menyebabkan revolusi 1952 dan keadaan sosial politik Mesir saat itu, yaitu ingin menggulingkan Raja Farouk yang dinilai oleh Ikhwanul Muslimin hanya sebagai boneka yang selalu melindungi kekuasaan koloni Inggris yang telah lama berada di Mesir. Raja Farouk ini tidak bisa tegas pada pendudukan asing pasukan Inggris yang masih bercokol di Zona Terusan. ${ }^{8}$

Dr. Muhammad Sayid Al Wakil menganalisa ada enam faktor yang menjadi penyebab Ikhwanul Muslimin mendukung revolusi ini yaitu: pertama, Raja Farouk mengangkat administratur kolonial Inggris dalam pemerintahan Mesir. Kedua, membekali pasukan mujahidin Mesir untuk Palestina dengan senjata yang rusak. Ketiga, mengadakan perjanjian damai dengan Israel dan menarik mundur pasukan Mesir dari Palestina pada saat teradi perang ArabIsrael. Keempat, selama masa pemerintahannya, Raja Farouk menyebarkan pengaruh negatif kebudayaaan Barat dan kerusakan moral. Kelima, Raja Farouk terlibat dalam skandal-skandal seks dan moralitas. Keenam, Raja Farouk dianggap terlibat dan bertanggung jawab pada peristiwa pembunuhan pendiri gerakan Al-Ikhwan Al-Muslimun, Imam Hasan Al- Banna. ${ }^{9}$

\footnotetext{
${ }^{7}$ Richard Paul Mithcell, Masyarakat Al-Ikhwan AlMuslimun : Gerakan Dakwah Al-Ikhwan Di Mata Cendekiawan Barat, ( Solo: Era Intermedia, 2005) hlm. 168.

${ }^{8}$ Richard Paul Mithcell, Masyarakat Al-Ikhwan AlMuslimun : Gerakan Dakwah Al-Ikhwan Di Mata Cendekiawan Barat, ( Solo: Era Intermedia, 2005) hlm. 140-141.

${ }^{9}$ Cahyadi Takariawan, Al-Ikhwan Al-Muslimun

: Bersama Mursyid 'Am Kedua, (Yogyakarta:

Tiga Lentera Utama, 2002) hlm. 58-59.
}

Akhir dari Revolusi Mesir 1952 adalah dimana para Perwira Bebas akhirnya bisa mengambil alih kekuasaan Raja Farouk baik politik maupun istananya dan juga menaikkan Jendral Neguib sebagai Presiden Mesir. Inilah pertama kalinya Mesir yang telah lama pemerintahannya berbentuk Monarki Absolut berubah menjadi sistem pemerintahan Republik Presidensil dengan Jendral Neguib sebagai Presiden. Raja Farouk yang sudah turun tahta langsung melarikan diri ke luar negeri dan mencari perlindungan ke negara-negara Sekutu yang telah bersahabat dengannya.

Selanjutnya, masa transisi dari Monarki Absolut ke Republik Presidensil ini telah mengubah Perwira Bebas menjadi Dewan Revolusi yang memiliki kekuasaan politik secara penuh untuk mengontrol dan memerintah Mesir secara efektif tanpa adanya campur tangan dari Sekutu. Ini adalah titik awal dimana pihak militer memegang kendali pemerintahan Mesir secara penuh dan menjadi awal dari otoritarianisme militer di Mesir.

Setelah memegang kendali pemerintahan secara penuh, militer mulai menganggap gerakan Ikhwanul Muslimin karena mereka menduga bahwa nantinya akan menjadi suatu gerakan oposisi yang membahayakan posisi militer sebagaI pemegang kendali tertinggi di Mesir. Jika melihat peranan Ikhwanul Muslimin yang sangat aktif dalam revolusi 1952, seharusnya Ikhwanul Muslimin menjadi mitra koalisi dan sudah sepantasnya mendapatkan power sharing yang pantas di pemerintahan yang dikuasai oleh militer. Tetapi kenyataannya, hubungan Ikhwanul Muslimin dan Militer semakin tidak berjalan dengan harmonis lagi.

Karena militer merasa yakin bahwa gerakan politik Ikhwanul Muslimin itu akan membawa ancaman bagi kedudukan militer, maka gerakan Ikhwanul Muslimin segera diberangus oleh Dewan Pimpinan Revolusi, Gamal Abdul Nasser. Banyak tokoh intelektual Ikhwanul Muslimin yang ditangkap dan dijebloskan ke 
dalam tahanan seperti Mursyid 'Am Ikhwan dan Ustadz Hasan Al Hudhaibi. Selain menjebloskan tokoh intelektual Ikhwanul Muslimin, militer juga memberangus gerakan Ikhwanul Muslimin dengan cara membakar seluruh kantor sekretariat yang berada di Mesir dan menangkap serta menculik para aktivis Ikhwanul Muslimin. Tujuan militer adalah menginginkan pemerintahan baru, damai yang bisa dikendalikan secara penuh tanpa ada kritikan dari organisasi politik seperti Ikhwanul Muslimin.

\section{Solidaritas Rakyat Mesir dan Revolusi 1952}

Negara dunia ketiga, termasuk Mesir, berada dalam masa peralihan dari keabsahan tradisional yang biasanya bersifat kesukuan atau religus menuju keabsahan rasional. Mereka senantiasa menjadi objek perbuatan negara-negara Barat yang lebih maju. Biasanya, negaranegara yang masih labil tersebut amat merindukan dua hal.

Pertama, birokrasi yang disokong oleh militer dalam rangka memandu jalannya kenegaraan dan, kedua, seorang yang mampu memimpin negara dan rakyatnya melewati masa-masa sulit tersebut dan membawa rakyatnya ke pintu kesejahteraan. Demikian isi surat Presiden Charles de Gaulle kepada Presiden Nasser yang agaknya sedikit menggambarkan kondisi Mesir yang masih belum mapan. ${ }^{10}$

Apa yang diucapkan de Gaulle agaknya merupakan kebenaran. Ketidakmapanan yang ada di Mesir, salah satu sumbunya adalah ketika Perang Dunia II berakhir. Kondisi Mesir kala itu masih berada dibawah kekuasaan Inggris. Inggris sadar bahwa di negeri itu harus ditempatkan suatu pemerintah perwakilan atas kuasanya. Untuk memenuhi harapan itu, pemerintah Inggris membentuk sebuah dewan pemimpin yang berasal dari para tuan tanah yang mengabdi sepenuhnya kepada kepentingan Inggris.

${ }^{10}$ Mohamed Heikal, Anwar Sadat; Kemarau Kemarahan, (Jakarta: Grafiti Press,1986 ) hlm. 47
Sekitar 1936, terjadi perombakan besar dalam tubuh kemiliteran Mesir. Pemerintah Mesir menerapkan suatu kebijakan baru yakni perekrutan tentara baru dengan standarisasi yang telah ditetapkan Inggris. Nantinya, tentara itu akan dijadikan sebagai tentara nasional. Hal ini dipandang para opsir, yang sebelumnya menjadi tentara nasional, sebagai salah satu bentuk peminggiran atas peran mereka. Agaknya, hal ini terkait dengan ideologi para opsir yang telah dirasuki oleh Islamisme, nasionalisme dan sosialisme. Paham yang terakhir, pada saat itu, selalu dianggap sebagai produk Rusia. Bagi mereka yang mengadopsinya, maka ia dianggap sebagai pengikut Moskow. Sejak kebijakan ini, hubungan pemerintah dengan Opsir Bebas mulai tidak harmonis.

Puncaknya, pada tahun 1949-1951, ketika opsir bebas dan aktivis komunis Mesir sadar bahwa Mesir perlu bebas dari Inggris yang telah lama bercokol di bumi Mesir. Kesadaran ini menghasilkan gelombang letupa-letupan kecil dimulai dari gelombang petani yang mengadakan pemberontakan terhadap tuannya. Perkebunan yang luas mereka rusak, sebagai bentuk protes atas kekuasaan abolut para pemilik tanah. Dalam sejumlah kasus, mereka juga menyerang para pengawal pribadi dan barak-barak kepolisian dengan persenjataan modern yang biasa disediakan oleh para simpatisan dalam satuan tentara. Yang menggerakkan pemberontakan ini,bukanlah berasal dari keinginan si petani sendiri, melainkan sengaja dibentuk oleh aktivis komunis Mesir. Selain itu, mereka juga menggalang persatuan para pedagang pedalaman serta mengirimkan mahasiswa dan dosen untuk memperkuat barisan petani dengan muatan ide-ide revolusioner.

Para Opsir Bebas sadar, perubahan atas Mesir baru harus segera dilakukan. Wacana Kudeta yang akan mereka laksanakan dipandang oleh orang sebagai langkah pertama menuju revolusi sosial di negara itu. Pemakzulan monarki itu menggairahkan rakyat dan memicu 
serangkaian perjuangan rakyat yang melampaui tujuan bahkan cita-cita dari opsir yang paling radikal sekalipun. Pada tanggal 13 Agustus 1952 sebuah serbuan dilakukan oleh para buruh ke pabrikpabrik milik Inggris. Rezim langsung menindak serangan itu dengan penindasan yang brutal dan tak kalah bengis. Sebuah pengadilan militer menetapkan dua pemimpin kelas buruh yang memeberontak itu sebagai tersangka dan langsung dijatuhi dengan hukuman mati.

Pada saat itu ada dua arus ideologi utama yang tren di negeri itu. Pengaruh komunis Mesir pada para petani, buruh dan bagian-bagian penting di kalangan terpelajar membuat gelisah pihak nasionalis. Penindasan dan ketidaksukaan rezim kepada aktivis komunis mengundang simpati dari seluruh negeri. Oleh karena kehilangan ideologi yang kohern yang biasa mereka gunakan melawan gerakan kiri, para Opsir Bebas mendekati Ikhwanul Muslimin yang puncaknya adalah penggalangan kerjasama antara mereka.

Pemilihan umum bebas terakhir Mesir yang diadakan pada bulan Januari 1950,telah mengubah peta kekuasaan lokal Mesir. Kekuasaan para tuan tanah digantikan dengan kemenangan partai Wafd. Fenomena ini ditanggapi Inggris dengan menciptakan pemisahan yang tajam di kalangan nasionlis ketika perdana menteri yang baru mengabari bangsa itu bahwa dia telah berada di ambang pembukaan kembali negosiasi dengan Inggris dan akan menandatagi suatu perjanjian dagang dengan Amerika Serikat membuat negara itu bergolak. Tercatat ada 49 serangan pada tahun 1950 dan demonstrasi massa terjadi di setiap kota. Arah tuntutan mereka adalah agar Inggris angkat kaki dari bumi Mesir. Dengan sia-sia menteri luar negeri Mesir meminta Inggris untuk memahami bahwa kehadiran mereka akan menyulut api pergolakan yang lebih besar.

Pihak Inggris menjawan usulan tersebut dengan sebuah jalan tengah, yakni mereka menolak untuk mundur dari Mesir kecuali pemerintah Mesir akan mengikuti aliansi dukungan Washington, terkait keikutsertaan Mesir dalam NATO. Pemerintah Mesir menolak jalan tengah itu. Sikap mandiri dan berani ini membangkitkan gelora rakyat untuk turun ke jalan berdemonstrasi. Di Ismailiya, laju demonstran tertahan oleh tembakan pasukan Inggris.

Pada bulan Januari 1952 polisi Mesir di Ismailiya berperang melawan tank- tank dan satuan altileri Inggris dan seluruh negeri menganggap bahwa tentara Mesir akan segera masuk ke dalam pertempuran yang lebih sengit. Hari berikutnya, sebuah pemogokan umum membuat seluruh negeri berhenti. Pra mahasiswa dan buruh berbaris ke pusat kota dan telah disambut perdana menteri yang menjanjikan pemutusan hubungan diplomatic dengan Inggris dan menjalin hubungan bilateral dengan Uni Soviet. Keadaan Mesir semakin tidak terkendali, ketika Ikhwanul Muslimin menggabungkan diri dalam demonstrasi dengan menyerang daerah bisnis dan tempat prostitusi di Mesir. Ikut sertanya Ikhwanul Musimin, membuat pemerintah Mesir panik dan menyatakan negeri Mesir sedang dalam keadaan bahaya.

Enam bulan kemudian, Para Opsir Bebas mengambil alih negeri yang terkoyak itu. dari delapan belas mayor dan pelaku yang terlibat dalam membangun gelombang revolusi militer itu, empat merupakan anggota Ikhwanul Muslimin (Sadat, Amer, Hussein, dan Mehanna), tiga lagi adalah Marxis (Khaled Mohiedin, Rifaat, Saddik) dan selebihnya adalah nasionalis yang berdiri dibelakang Gamal Abdul Nasser. Opsir Bebas bukan hanya mengandalkan kemampuan militer semata, melainkan juga membekali diri dengan kebiasaan membaca yang tinggi. Mereka juga sering mengadakan diskusi dengan perdebatanperdebatannya yang seru. Yang lain, lebih suka menghadiri berbagai diskusi yang diampu oleh para intelektual kenamaan. 
Mendekati tahun 1950, organisasi ini telah memiliki ratusan anggota. Umumnya, anggotanya terdiri dari pemuda, tentara bawahan dan banyak pula diantara mereka yang merupakan murid Nasser. Organisasi ini memiliki 3 prinsip kunci: 1) Menyingkirkan raja dan komplotannya; 2) memangkas imperialism Inggris; 3) penggunaan kekuatan militer sebagai alat mewujudkan cita-citanya. ${ }^{11}$

Salah satu dari sekian mentor studi yang menonjol adalah Gamal Abdul Nasser. Sebagai dosen sejarah di Akademi Militer, Gamal Abdul Nasser memiliki pengaruh langsung pada anggota baru. Di ruang-ruang studi ia memberi kuliah tentang kemenangankemenangan militer orang-orang Arab generasi awal, serta cahaya terang dari dunia keilmuan Islam ketika Eropa sedang tidur di abad kegelapan. ${ }^{12}$ Dia mengajarkan muridnya bagaimana Islamketika Renaisans menyingsingmenyerahkan warisannya ke dunia Barat, sementara ia terperosok ke dalam ketumpulan dan kemunduran. Kejayaan masa silam sangat hebat, tapi tak akan pernah kembali. Sekarang, seorang harus berpikir kreatif untuk membangun kembali kesadaran nasional dunia Arab, mengkampanyekan dan memodernisasikannya. ${ }^{13}$

Peran Nasser amatlah penting dalam Opsir Bebas. Lewat organisasinya ini ia mengampanyekan nasionalismenya lebih ke arah praksis dan politis bukan sekedar wacana yang hidup di kalangan intelektual tanpa mengarah ke objek penderitaan masyarakat Mesir. Ialah yang turut serta membentuk Opsir Bebas sepulangnya dari perang melawan Israel tahun 1949. Maksud pembentukan organisasi ini adalah mengambil alih pimpinan Mesir dari tangan rezim yang berkuasa. Ia sempat melontarkan katakata penuh luapan nasionalise: "kami

\footnotetext{
${ }^{11}$ Lewis, The Modern Middle East ,hlm. 123.

${ }^{12}$ Lihat Mehdi Nakosteen, Kontribusi Islam atas

Dunia Barat, (Surabaya: Risalah Gusti, 2003), hlm. 255-279.

${ }^{13}$ Ali, Benturan Antar, hlm. 106-113.
}

berperang di Palestina namun mimpi kami ada di Mesir. ${ }^{14}$

Tak dapat dipungkiri, para Opsir Bebas memainkan peran yang vital dalam menggalang kekuatan massa yang besar untuk menunjukkan pada dunia bahwa Mesir akan bebas. Strategi politiknya amatlah licin sehingga mampu fleksibel merangkul Ikhwanul Muslimin dalam satu barisan untuk sama-sama mengusir bangsa Barat dari bumi Mesir.

Setelah membaca sejarah panjang kemerdekaan Mesir di atas, maka akan terlihat semangat penduduk Mesir yang bahu membahu keluar dari kolonialisme Inggris dan keinginan kuat untuk menjadi negara yang mandiri. Di sini akan terlihat betapa masyarakat Mesir kususnya yang berada di Kairo telah menggunakan semacam kekuatan solidaritas sosial untuk menyamakan visi menjungkalkan Inggris.

Ketika membedah jenis gerakan revolusi Mesir, maka tidak terlepas dari kolonialisme Inggris yang menimbulkan "kejahatan" di tengah warga Mesir. Kejahatan di sini tentu saja bukan dalam artian kriminalitas maupun setumpuk aksiaksi merugikan lainnya tanpa ada sebab dan murni hanya untuk bertindak menyimpang semata. Kejahatan yang tercipta adalah bentuk pemberontakan kepada kekuasaan yang menindas. Hal ini saja tak cukup. Sebagaimana telah disinggung di atas, para Opsir juga memberikan semacam penyuluhan agar para petani "membuka mata" bahwa sesungguhnya pemimpin mereka telah berbuat dzalim. Ketika kesenjangan sosial mulai merajalela ditambah dengan perilaku apatis para pemuka masyarakat yang hanya menjadi robot bagi kepentingan Inggris.

Belum lagi, keberhasilan melobi Ikhwanul Muslimin juga merupakan bentuk solidaritas sosial lain yang tak kalah penting dalam organ para revolusoner Mesir. Al Banna sendiri, mengaggap bahwa Islam bukan hanya agama melainkan doktrin penyembahan,

${ }^{14}$ Lewis, The Modern Middle East, hlm. 123. 
tanah air, kebangsaan, agama, keruhaniaan dan pedang. ${ }^{15}$ Jadi, sosialisme yang diadopsi oleh para Opsir menemukan "kesamaan" dengan cara pandang alBanna bahwa penjajahan atas Mesir sama halnya dengan menduduki tanah air yang mereka tinggali selama berabad-abad.

Pengorganisasian massa yang terdiri dari cendikiawan, mahasiswa, petani dan pedangang merupakan sebuah barisan besar yang cukup untuk memakzulkan Raja Farouk yang kala itu berkuasa. Gerakan besar ini merupakan wujud dari ketentraman yang ditekan lalu muncullah "kejahatan" yang menghampiri dan akan menghukum si penekan. Solidaritas sosial yang terbangun di Mesir adalah kumpulan dari kemarahan, kegelisahan dan kesamaan rasa para masyarakatnya.

Jika melihat kasus revolusi Mesir 1952, maka solidaritas yang cocok untuk membaca ulang peristiwa tersebut adalah dengan kaca mata solidaritas organik. Hal ini ditunjukkan dengan kompleksnya kelompok masyarakat yang ikut serta dalam menjemput "pesta besar" tersebut. Kendati diinisiasi oleh dua gerbong politik oposan, Opsir Bebas dan Ikhwanul Muslimin, agaknya kelompok lain juga ikut berperan aktif dalam menciptakan perubahan sosial itu. Peran polisi yang menghalau pasukan Inggris dan pemberontakan para petani atas tuan tanahnya yang menjadi boneka Inggris merupakan beberapa contoh yang semakin menandaskan beragamnya profesi dan status sosial para aktok dibalik pemakzulan rezim yang berkuasa.

Selanjutnya, kesadaran kolektif bangsa Mesir, bersandarkan pada uraian Durkheim di atas, adalah akibat berbagai tindakan represif yang dilakukan para tuan tanah yang kendati berasal dari bangsa yang sama, tetapi memiliki orientasi politik yang berbeda. Sebagaimana diketahui, setiap manusia tentu lahir dalam keadaan bebas. Kebebasan tersebut termasuk pula dalam mengolah kekayaan alam di mana ia hidup. Lalu, kondisi harmonis ini akan berubah menjadi kekuatan perlawanan jika rasa kebebasan itu mulai dicederai oleh orang lain. Begitu pula yang dialami oleh rakyat Mesir yang telah lama mengalami kolonialisasi bangsa Barat. Dalam pada itu, perlawanan yang dilakukan oleh banyak elemen masyarakat mulai dari tentara, pelajar, petani, agamawan dan lain-lain merupakan perwujudan dari kesadaran kolektif untuk meretas jalan pembebasan atas segala bentuk belenggu sosial.

\section{Militer Jerman di Mesir}

Hancurnya kekuasaan Nazi di mata Eropa menyebabkan para aktivisnya harus hidup dalam suasana ketidaktenangan. Beberapa dari mereka ada yang menjalani hukuman penjara, tidak sedikit dari mereka yang memutuskan untuk meninggalkan Jerman. Selain Amerika Selatan, para aktivis Nazi dikabarkan banyak menyebar di negara-negara Arab. Yang cukup menarik perhatian, adalah banyaknya mantan petinggi Gestapo, salah satu organisasi elit yang bernaung di bawah Nazi, tidak hanya tinggal di Arab, tetapi juga hidup dengan menggunakan namanama Arab.

Salah satu tujuan pelarian yang menarik perhatian mereka adalah Mesir. Menjelang kejatuhan Raja Farouk, Nasser banyak mendatangkan ilmuwan-ilmuwan ahli persenjataan Nazi sebagai penasehat militernya. Ini menjadi suatu indikasi betapa pengaruh Perang Dunia II, lewat para aktor-aktornya ikut serta dalam barisan yang menyokong Nasser, sebagai salah satu anggota Opsir Bebas yang paling berpengaruh. Agaknya, sebelum meletupkan revolusi 1952, Nasser sudah lebih dini untuk memperkuat kekuatan militernya, terlebih ketika menghubungkannya dengan keadaan politik luar negeri Mesir yang masih labil. Sebagaimana telah disebutkan, Mesir berhasil mengusir Inggris dari tanahnya. Inggris sebetulnya sudah jauh hari menyiapkan sahabat Yahudinya, yang telah"mewakili" kepentingannya di Timur Tengah lewat berdirinya negara

${ }^{15}$ M. Riza Sihbudi, Bara Timur Tengah, hlm, 102. 
Israel pada 1948, lewat Deklarasi Balfour pada tanggal 2 November 1917, di mana Palestina, yang menjadi jajahan Inggris, diserahkan kepada umat Yahudi. Bangsa Yahudi sendiri banyak yang membantu Inggris dalam Perang Dunia I. Pendirian Israel, tentu saja sangat didukung oleh Inggris.

Mesir yang kala itu sedang menyambut revolusi, telah menyiapkan diri, lewat modernisasi bidang militer. Hal ini dilakukan untuk mencegah terjadinya gelombang serangan balasan balasan Inggris yang lebih besar, lewat Israel. Salah satu langkah yang jitu untuk mendongkrak teknologi persenjataan Mesir, adalah dengan mendatangkan para ahli dari luar.

Suatu laporan memberitakan bahwa hampir setiap hari selama tahun 1950an, beberapa orang Jerman berkumpul di pabrik bir Löwenbrau di Jalan Dua Puluh Enam Juli, Kairo. Seorang agen yang diminta untuk tetap mengawasi pabrik itu mencoba membuntuti orang-orang Jerman itu ke rumahnya. Hasilnya diketahui, menjelang runtuhnya Raja Farouk, seorang Jerman bernama Dr. Wilhelm Voss telah datang ke Kairo untuk menawarkan keahliannya di bidang persenjataan. Nasser, tanpa piker panjang, langsung memberikannya tugas untuk memimpin pembuatan roket kaliber kecil dan beberapa proyek militer yang skalanya lebih besar.

Dahulu, Voss bekerja sebagai pelaksana dalam pabrik senjata Hermann Goering di Jerman dan juga pemimpin pabrik Skoda Di Cekoslowakia selama pendudukan Jerman. Tak lama kemudian, Nasser menunjuk Voss sebagai direktur CERVA, organisasi Mesir untuk embuat senjata roket taktis, dan sebagai asistennya, ditunjuk Profesor Paul Goercke, seorang spesialis elektronika yang dulu ikut dalam tim pembuat rudal andalan Nazi bernama V1s.

Kedatangan Voss, merupakan pembuka dari masuknya para imigran Jerman mantan Nazi ke Mesir. Tak jarang untuk menutupi identitasnya mereka mengganti namanya dengan nama Arab. Orang yang bernama Mohammed Hassein adalah nama samaran Jurgen Knethch, mantan pejabat kebudayaan Nazi di Montevideo. Yang lain, orang Mesir menyebutnya Mohammed Akbar alias mantan Letnan SS Ulrich Kraus. Ada pula bekas kepala Gestapo Warsawa, Leopold Gleim dan staf di kamp konsentrasi Nazi di Mauthausen.

Mereka semua kerapkali berkumpul di pinggiran Kairo. Orang yang bertugas mengumpulkannya adalah Dr. Johannes von Leers, salah satu staf utama Menteri Propaganda Nazi, Dr. Joseph Goebbels. Beberapa orang Jerman diselundupkan ke Mesir lewat jejaring yang disusun oleh Countess d'Andurian, namun, kedatangan orang Jerman ke Mesir baru ramai pada sekitar tahun 1950 .

Salah satu ketergantungan Mesir atas ahli-ahli teknologi Jerman, adalah pengadaan pesawat terbang. Deacon menyebutkan, di luar Kairo telah didirikan pabrik yang membuat komponen pesawat supersonik di bawah pimpinan ahli pesawat terbang Jerman, Willy Masserschmitt. Selain itu beberapa rudal juga sering meluncur dari sekitar pemukiman Jerman.

Beberapa uraian di atas cukup menggambarkan betapa unsur-unsur Perang Dunia II ikut mewarnai haru biru perjuangan rakyat Mesir. Kendati belum ditemukan keterlibatan atau pengaruh langsur dari PD II, namun penggalanpenggalan informasi di atas dapat dijadikan sandaran adanya jejak NAZI sebagai salah satu aktor kunci di PD II. Boleh dikatakan modernisasi bidang kemiliteran Mesir pada tahap awal kemerdekaannya tak lepas dari kontribusi ilmuwan-ilmuwan Nazi.

\section{Kesimpulan}

Pengaruh Perang Dunia II terhadap perjuangan kemerdekaan Mesir di bidang politik-militer, sangat kuat. Di bidang politik, Mesir menginginkan kebebasan dan ketiadaan kontrol dari Inggris. Selain itu, Mesir juga mengubah sistem 
Pemerintahannya dari monarki absolut, menjadi Republik Presidensial. Serta sangat kuatnya perkembangan paham komunisme, sosialisme dan liberalisme di Mesir. Sedangkan di bidang militer, Mesir memodernisasi militer dan persenjataannya dengan cara mendatangkan ilmuwanilmuwan ahli persenjatan Nazi dalam pembuatan roket kaliber kecil dan beberapa proyek militer yang skalanya lebih besar seperti pembuatan pesawat supersonic di bawah pimpinan ahli pesawat terbang Jerman, Willy Masserschmitt.

Kemenangan partai Wafd pada tahun 1930 pada Pemilu Mesir, semakin menancapkan paham sosialisme yang semakin hidup di tengah masyarakat. Proposal jalan tengah Inggris kemudian ditolak mentah-mentah oleh pemerintah baru Mesir yang ternyata lebih condong ke arah Soviet. Kebuntuan ini melahirkan tindakan represif tentara Inggris yang berhadapan langsung dengan rakyat di kotakota besar seperti di Ismailiya dan Kairo. Negara semakin tidak terkontrol dan pemerintah Mesir mengumumkan negaranya dalam keadaan gawat.

Pada posisi inilah Opsir Bebas menemukan momentumnya. Mereka bergerak cepat menggandeng Ikhwanul Muslimin yang ternyata berhaluan sama dengan mereka yakni untuk mengusir tangan-tangan Inggris dari Mesir. Puncaknya, demostrasi masif yang dibumbui dengan aksi-aksi perawanan berujung pada penggulingan Raja Farouksang pemimpin boneka Inggris-pada tahun 1952. Kesuksesan ini adalah karena solidaritas yang kuat sebagai "bangsa tertindas" yang direalisasikan dengan aksi demostrasi dan tuntutan pemakzulan pemimpin. Opsir Bebas mempunyai peran sentral dalam mewujudkan revolusi ini.

\section{Daftar Pustaka}

\section{Buku}

Abdullah, Taufik dkk. (Pany.), Durkheim dan Pengantar Teori Sosiologi Moralitas, (Jakarta Yayasan Obor Indonesia, 1986).
Abdurrahman, Dudung, Metode Penelitian Sejarah (Jakarta: Logos Wacana Ilmu, 1999).

al-Afifi, Abdul Hakim, "1000 Peristiwa Islam" (Bandung: Pustaka Hidayah, 2002). Alejandro, Emdievi Y.G, 41 Diktator Zaman Modern, (Jakarta: Visimedia, 2007). Ali, Tariq, Benturan Antar Fundamentalis, (Jakarta: Paramadina, 2004).

Aji, Darma, Menantang Diktator, (Jakarta: Kompas, 2005).

Amal, M. Adnan, Portugis dan Spanyol di Maluku (Depok: Komunitas Bambu, 2010).

Ansary, Tamim, Dari Puncak Baghdad; Sejarah Dunia Versi Islam (Jakarta: Zaman, 2010).

Barents, J., Pengantar Ilmu Politik, (Jakarta: Erlangga, 1983).

Basyar, Hamdan M. (ed), Problematika Minoritas Muslim di Israel, (Jakarta: Pusat Penelitian Politik LIPI, 2002).

Brockelmann, Carl, History of Islamic Peoples, (London: Routldge and Kegan Paul Limited, 1949).

Carpentier, Jean dkk. , Sejarah Perancis (Jakarta: Kepustakaan Populer Gramedia, 2011)

Catherwood, Christopher, A Brief History of The Middle East (New York: Carroll and Graf Publishers, 2006).

Deacon, Richard, Dinas Rahasia Israel bagian 1(Jakarta: Laras Widya Pustaka, 1986).

Durkheim, Emile, The Division of Labor in Society, translated by George Simpson (New York: Free Press, 1964).

Esposito, John L., Ancaman Islam: Mitos atau Realiti, (Kuala Lumpur: PTS Publication, 2004).

Gottschak, Louis, Mengerti Sejarah,(Jakarta: UI Press, 1969).

Hadi, Amirul, Aceh; Sejarah, Budaya, dan Tradisi (Jakarta: Yayasan Obor Indonesia, 2010).

Hart, Michael H., Seratus Tokoh yang Paling Berpengaruh Dalam Sejarah, (Bandung: Pustaka Jaya, 2001). 
Heikal, Mohamed, Anwar Sadat; Kemarau Kemarahan, (Jakarta: Grafiti Press, 1986) Hourani, Albert, Pemikiran Liberal di Dunia Arab, (Bandung: Mizan, 2004)

Iqbal, Akhmad, Perang-Perang Paling Berpengaruh di Dunia, (Jakarta: JB Publisher, 2010).

Johnson, Doyle Paul, Teori Sosiologi Klasik dan Modern jilid I (Jakarta: Gramedia, 1988).

Jones, Pip, Pengantar Teori-Teori Sosial, (Jakarta: Yayasan Obor Indonesia, 2010)

Kuncahyono, Trias. Jerusalem: Kesucian, Konflik, dan Pengadilan Akhir, (Jakarta: Kompas, 2009).

Lanza, Conrad H., Napoleon dan Strategi Perang Modern, (Depok: Komunitas Bambu, 2010).

Lewis, Bernard, Apa yang Salah, (Jakarta: PT Ina Publikatama, 2004). , The Modern Middle East (London: University of California Press, 2005).

Loon, Hendrik Willem van, The Story of Mankind, (USA: Bonnie and Liveraight Inc., 1922).

Marbun, B.N., Demokrasi Jerman, (Jakarta: Sinar Harapan, 1983). Misrawi, Zuhairi, Al-Azhar, (Jakarta: Gramedia: 2010).

Mithcell, Richard Paul, Masyarakat AlIkhwan Al-Muslimun: Gerakan Dakwah Al- Ikhwan Di Mata Cendekiawan Barat (Solo: Era Intermedia, 2005).

Nakosteen, Mehdi, Kontribusi Islam atas Dunia Barat, (Surabaya: Risalah Gusti, 2003).

Nasution, Harun. Pembaharuan Dalam Pemikiran Islam Sejarah Pemikiran dan Gerakan (Jakarta: Bulan Bintang, 1975).

Ojong, P.K. Perang Eropa Jilid I. (Jakarta: Kompas, 2003). Quarrie, Bruce, Wafen SS, (Jakarta: Kompas, 2005).

Romli, M. Guntur, Musim Feminis (Jakarta: Freedom Institute, Cetakan Pertama, 2010)
Said, Mohammad, Aceh Sepanjang Abad jilid 1, (Medan: Waspada, 1981). Samekto, Ikhtisar Sejarah Bangsa Inggris, (Jakarta: Grasindo, 1998).

Syihbudi, M. Riza, Bara Timur Tengah, (Bandung: Mizan, 1991).

Takariawan, Cahyadi, Al-Ikhwan AlMuslimun : Bersama Mursyid 'Am Kedua (Yogyakarta: Tiga Lentera Utama, 2002).

Travelyan, G.M., Illustrated History of England, (London: Longman, 1956).

Vlekke, Bernard H.M., Nusantara; Sejarah Indonesia (Jakarta: Kepustakaan Populer Gramedia dan Freedom Institute, 2008).

Yatim, Badri, Historiografi Islam, (Ciputat: Logos Wacana Ilmu, 1997).

\section{Sumber Internet}

http://www.unog.ch/80256EE60057D930/( httpPages)/1247483E6FED755A80256EF8 004FE8FD?OpenDocument

http://www.historyplace.com/worldwar2/ti meline/ends2.htm

http://www.ushmm.org/wlc/en/article.php?

ModuleId $=10005263$

http://www.mengele.dk/

http://www.worldwar-2.net/

http://www.spartacus.schoolnet.co.uk/2WW egypt.htm

http://www.jewishvirtuallylibrari.org.

http://www.britannica.com

www.historylearningsite.co.uk

Www.ibiblio.org

www.sis.gov.eg

www.Archives.com

\section{Terbitan Berkala}

Journal of the Straits Branch of the Royal Asiatic Society vol. 7, (Singapore, 1887). 
